\title{
Consumer Behavior Driven Models to Improve Waste Mobile Phone Recycling
}

\author{
Tuan Hai Nguyen and Chun Wei Remen Lin
}

\begin{abstract}
The paper examines consumer behaviors with the existing business models in waste mobile phone recycling throughout the questionnaire which collected online and offline. The survey will conduct in Taiwan and Vietnam from college students by google forms online. It includes the existing business models which utilized some business models for making profits for producers like vending machines, monetary incentives or information technology solutions with logistic services to return their unused mobile phone back to recycling process or second hand market. Understanding this issues, people will have evidence to reduce the waste mobile phone directly and indirectly for the environment by making profit. The paper also investigates whether consumers would like to use second hand mobile phone or not. The results can help improve the policy-making for both producer and government related. The paper emphasizes on monetary incentives and IT solutions which included in environmental protection fees in the original price.
\end{abstract}

Keywords - consumer behavior, waste mobile phone recycling, business models, information technology solutions, monetary incentives..

\section{INTRODUCTION}

In recent times, the fierce competition in the market has made mobile phone companies race to shorten the lives of their phones thanks to developments of information technology. Thus, on average, every six months, cell phones are launching new mobile versions, for instance, iphone 6 and iphone $6 \mathrm{~S}$, iphone 7 in the reality. As a result, the amount of mobile phone is significantly increasing (Panambunan-Ferse and Breiter, 2013). The shorter the lifecycle of a mobile phone means the more e-waste is released into the environment; and this contributes a significant portion to global e-waste with more than 50 million tonnes annually (Ni and Zeng, 2009).

Recycling from electronic waste is becoming increasingly urgent. Indeed, enormous amounts of e-waste are discharged each year, more than 50 million tons. If the manufacturing and government businesses effectively manage the recycling of ewaste, this not only collects valuable substances including $\mathrm{Cu}$, $\mathrm{Al}, \mathrm{Au}, \mathrm{Fe}, \mathrm{Ni}, \mathrm{Si}, \mathrm{Cd}, \mathrm{Cr}$ and $\mathrm{Pd}$, and any other e-waste material (Robinson, 2009), but also protect the environment.

One of the most effective measures is to use economic measures to increase consumer behavior so as to have measures to recycle rubbish from the mobile phone in a reasonable and economical way. This research will identify the

Tuan Hai Nguyen, Asia University, Taiwan, R.O.C

Chun Wei Remen Lin, Asia University, Taiwan, R.O.C business model which have positive effects for recycling issues related to consumer behaviors, based on the survey from college students. The idea for this research papers mentioned as the table 1 .

TABLE I

THE IDEA FOR THE PAPER
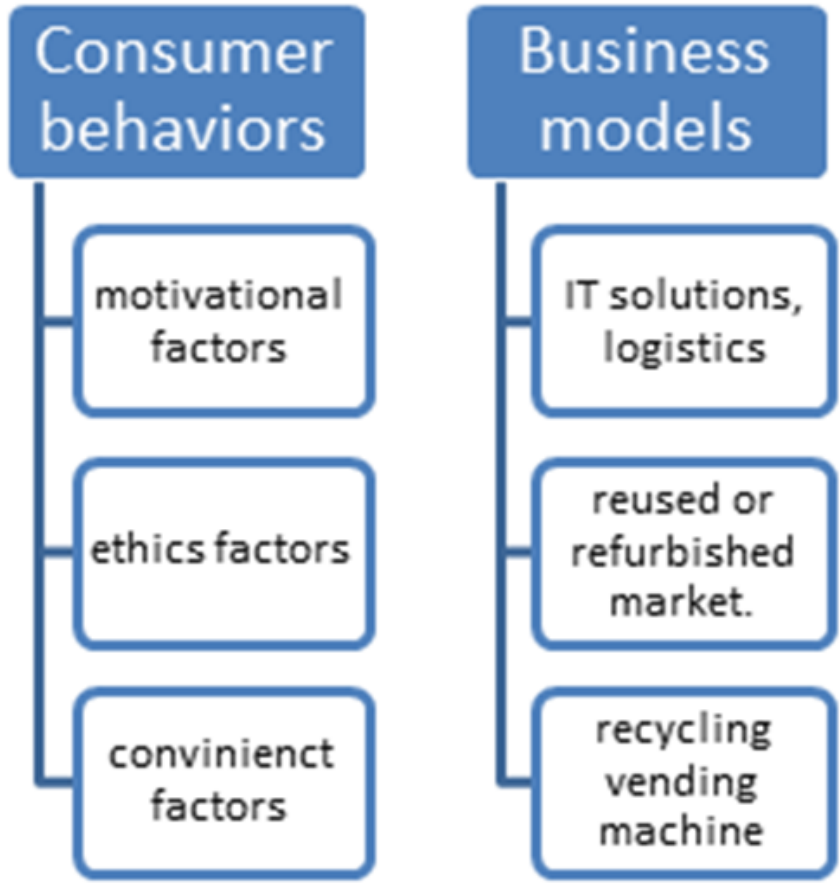

A. The objective of study

The objective will answer the following research questions:

RQ 1: What are the reasons for failing to return mobile phones for recycling?

RQ 2: How is the consumer's treatment for unused or waste mobile phone?

RQ 3: What is the consumers' environmental awareness of mobile phone recycling?

\section{LITERATURE REVIEWS}

\section{A. The rise of mobile phone waste}

The development of the world is increasingly based on the internet like the theory about internet of things. Along with that development, mobile waste has been rising rapidly as an inevitable consequence. Polák and Drápalová (2012) had an article which described the increasing the quantity in numbers of discarded mobile phones from 45 thousand in the decade 
1990-2000 up to 6.5 million in the next decade, 2000-2010 and predicted that this number would significantly rise to around 26 million in this decade period, 2010-2020. In addition, Rahmani et al. (2014) estimated that about 39 million mobile phones was become waste ones until 2014 and anticipated that this figure would arrive at 90 million by 2035 . In another study in Nigeria from the articles of Babatunde et al. (2014), $40 \%$ of the surveyed population used a mobile phone in one year, so this explained partly the reasons why waste mobile phone was risen in recent decades.

\section{$B$. The convenience of recycling}

Source separation for dry recyclables in many communities are increasingly a popular activity (Thomas and Sharp, 2013). However, some studies illustrated the inconvenience of recycling systems and economic disincentives such as return fees, extra trips (Barr et al., 2001; Bouvier and Wagner, 2011; Wagner, 2013). People who surveyed in a research in Stockholm, Sweden accepted legal norms although the satisfaction with the facilities did not correlate with recycling behaviour (Miafodzyeva et al. 2013). In addition to this, Ramayah et al. (2012) found that norms influence strongly on recycling behaviour in a collectivistic society compared to individual convenience. Wagner (2013) has recognized five categories of convenience in order to assess the convenience of collection schemes are (1) knowledge requirements, (2) proximity to the collection point/site, (3) opportunity to dropoff materials, (4) inducement of the collection point/site (e.g. desirability or availability of services), and (5) ease of the process. According to this study of Wagner (2013), a high convenience of collection system means easily obtainable and centrally located multiple collections with minimal efforts to obtain and/ or provide information in the course in returning procedures.

\section{MethodologiES}

\section{A. Survey}

The survey will collect information from college students who are mainly learning in Vietnam or Taiwan. This will conduct online throughout google forms online or based on questionnaire given for them.

\section{B. The questionnaire}

The questionnaire has 5 parts which includes basic information, consumer's treatment for unused or waste mobile phone, consumers' environmental awareness, motivational, convenient, and ethics elements for returning the waste or unused mobile phone, and suggestions and recommendations. In order to understand about consumer behaviors, audiences, readers, reviewers should see the first three parts, but for the solutions and others suggestion and recommendation from those surveyed, they should view part 4 and 5 in the questionnaire. After finished the questionnaire, authors will draw tables to figure out the solution for the problems and solutions for the topic of paper.

\section{RESULTS}

\section{A. The basic information}

The paper investigated in groups at Chung Yuan Christian university, Asia university (all in Taiwan), and Bac Lieu university (Vietnam) and there are 23 given answers. As the figure below showed, there are $52.4 \%$ female and $47 \%$ male surveyed; they are from many countries like Indonesia, Vietnam, India, etc. Most appraised people in the same countries are from Indonesia and Vietnam. Also, majority of them is living in the cities and minority of them is in the suburban. Only $19 \%$ people are working and $81 \%$ are studying because the survey was conducted in colleges or universities. In addition, the age of them fluctuated from 19 to 45; and most of them are at graduate level.

\section{B. Consumer's treatment for unused or waste mobile phone}

The highest proportion of investigated people has used their mobile phone for more than 3 years, following by the period 2 years to less than 3 years. Only 19\% people used their mobile phone from 1 to less than 2 years.

TABLE II

How long is the average service life of your mobile phone?

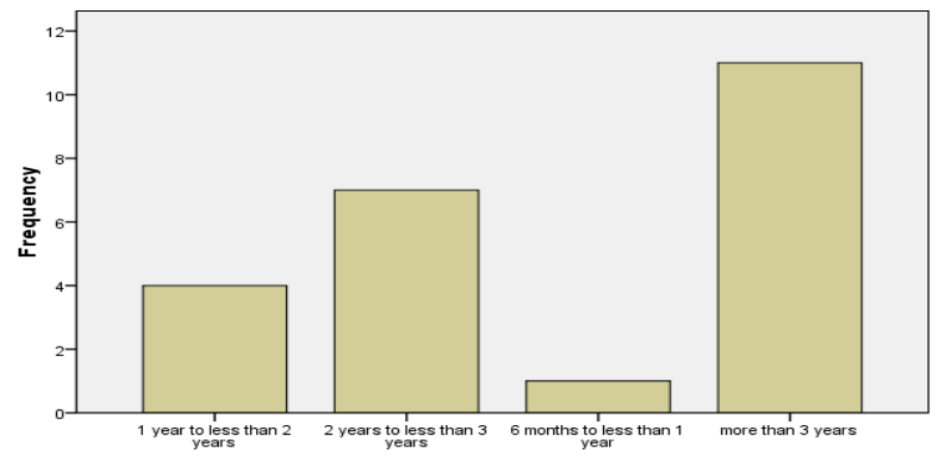

What is the reason for replacing your mobile phone?

\begin{tabular}{|c|c|c|c|c|c|}
\hline & & Frequency & Percent & Valid Percent & $\begin{array}{c}\text { Cumulative } \\
\text { Percent }\end{array}$ \\
\hline \multirow[t]{5}{*}{ Valid } & Damage & 13 & 56.5 & 56.5 & 56.5 \\
\hline & Outdated function & 6 & 26.1 & 26.1 & 82.6 \\
\hline & 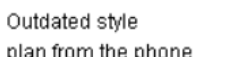 & 3 & 13.0 & 13.0 & 95.7 \\
\hline & $\begin{array}{l}\text { company, new phone is } \\
\text { part of the plan as free }\end{array}$ & 1 & 4.3 & 4.3 & 100.0 \\
\hline & Total & 23 & 100.0 & 100.0 & \\
\hline
\end{tabular}

The most reason to replace mobile phone is damage; it means that people will buy a new one when their mobile phone was broken. Outdated function and outdated style is also the following reasons in replacing an old mobile phone to a new one. From the below figure, many people have their unused mobile phone at home and the highest ways they treat their waste mobile phone was stored at home or sold to the peddler and second hand market. 
TABLE III

\begin{tabular}{|c|c|c|c|c|c|}
\hline \multicolumn{6}{|c|}{ How do you treat your waste mobile phone? } \\
\hline & & Frequency & Percent & Valid Percent & $\begin{array}{c}\text { Cumulative } \\
\text { Percent }\end{array}$ \\
\hline \multirow[t]{7}{*}{ Valid } & $\begin{array}{l}\text { Given to my family } \\
\text { member or relatives }\end{array}$ & 3 & 13.0 & 13.0 & 13.0 \\
\hline & $\begin{array}{l}\text { I keep it. One of them is } \\
\text { used sometimes for } \\
\text { listening to music. The } \\
\text { other two stored at home, } \\
\text { used only in emergency }\end{array}$ & 1 & 4.3 & 4.3 & 17.4 \\
\hline & $\begin{array}{l}\text { Recycled by Old-for-New } \\
\text { activity }\end{array}$ & 1 & 4.3 & 4.3 & 21.7 \\
\hline & $\begin{array}{l}\text { Sold to the peddler and } \\
\text { second-hand market. }\end{array}$ & 5 & 21.7 & 21.7 & 43.5 \\
\hline & Stored at home & 12 & 52.2 & 52.2 & 95.7 \\
\hline & Use in other funtion & 1 & 4.3 & 4.3 & 100.0 \\
\hline & Total & 23 & 100.0 & 100.0 & \\
\hline
\end{tabular}

TABLE IVA

THE WAY TO TREAT WASTE MOBILE PHONE

\begin{tabular}{|c|c|c|c|c|}
\hline & Frequency & Percent & Valid Percent & $\begin{array}{c}\text { Cumulative } \\
\text { Percent }\end{array}$ \\
\hline Valid & 3 & 13.0 & 13.0 & 13.0 \\
\hline $\begin{array}{l}\text { Authorized stores, retail } \\
\text { stores. }\end{array}$ & 3 & 13.0 & 13.0 & 26.1 \\
\hline $\begin{array}{l}\text { Authorized stores, retail } \\
\text { stores.;Friend }\end{array}$ & 1 & 4.3 & 4.3 & 30.4 \\
\hline $\begin{array}{l}\text { Authorized stores, retail } \\
\text { stores.;Old phone shop. }\end{array}$ & 1 & 4.3 & 4.3 & 34.8 \\
\hline $\begin{array}{l}\text { Authorized stores, retail } \\
\text { stores:;Old phone shop.; } \\
\text { Peddler:; Sold online } \\
\text { through a website. }\end{array}$ & 1 & 4.3 & 4.3 & 39.1 \\
\hline $\begin{array}{l}\text { Authorized stores, retail } \\
\text { stores:OOld phone shop.; } \\
\text { Sold online through a } \\
\text { website. }\end{array}$ & 1 & 4.3 & 4.3 & 43.5 \\
\hline Not sell & 4 & 17.4 & 17.4 & 60.9 \\
\hline Old phone shop. & 4 & 17.4 & 17.4 & 78.3 \\
\hline $\begin{array}{l}\text { Old phone shop : Sold } \\
\text { online through a website. }\end{array}$ & 3 & 13.0 & 13.0 & 91.3 \\
\hline Peddler. & 1 & 4.3 & 4.3 & 95.7 \\
\hline $\begin{array}{l}\text { Sold online through a } \\
\text { website. }\end{array}$ & 1 & 4.3 & 4.3 & 100.0 \\
\hline Total & 23 & 100.0 & 100.0 & \\
\hline
\end{tabular}

People usually sell their old mobile phone to old phone shop and/or authorized stores or retail stores. Additionally, they keep their unused mobile phone as a spare phone or they would like to give the phone to families or friends rather than recycle it at a low price. However, the high proportion of surveyed people did not where they take it. Thus, authorities should take some measures to reduce the number. There are many preference patterns of waste mobile phones from audiences, including Old-for-New activity, door-to-door collecting service, business hall of mobile telecom carrier, service center and maintenance center.

\section{Consumers' environmental awareness}

There are some ideas to put an old or waste mobile phone to the mixed waste bin, but in this paper, the advice is that we should not make the mixed waste bin with included waste electronic electricity equipment because people did not desire the idea.

TABLE V

\begin{tabular}{|c|c|c|c|c|c|}
\hline & & Frequency & Percent & Valid Percent & $\begin{array}{c}\text { Cumulative } \\
\text { Percent }\end{array}$ \\
\hline \multirow[t]{3}{*}{ Valid } & No & 5 & 21.7 & 21.7 & \multirow{3}{*}{$\begin{array}{r}21.7 \\
100.0\end{array}$} \\
\hline & Yes & 18 & 78.3 & 78.3 & \\
\hline & Total & 23 & 100.0 & 100.0 & \\
\hline
\end{tabular}

Many people concerned about recycling mobile phones with $76.2 \%$, so consumers will follow campaign related to recycle in this field. Thus, producers or authorities should create some suitable events in the problems regarding waste mobile phones if they think it is necessary.

Many people know about the toxic and hazardous substances inside the waste mobile phones. They also recognize the precious metal substances like gold, silver, or palladium. In addition to this, many people agree to buy used or refurbished mobile phones, but the prerequisites for buying a used mobile phone arrange in priority order: (1) It has features that the current mobile phone does not have; (2) It is cheaper to buy a used phone than a new one; (3) The old mobile phone is no more than one-year-old.

TABLE VI

Do you know that waste mobile phones contain toxic and hazardous substances, such as lead, mercury, or arsenic?

\begin{tabular}{|ll|r|r|r|r|}
\hline & & & & \multicolumn{2}{c|}{$\begin{array}{c}\text { Cumulative } \\
\text { Percent }\end{array}$} \\
\hline Valid & Frequency & Percent & Valid Percent & 13.0 \\
& No & 3 & 13.0 & 13.0 & 17.4 \\
& Not sure & 1 & 4.3 & 4.3 & 100.0 \\
Yes & 19 & 82.6 & 82.6 & \\
\hline & 23 & 100.0 & 100.0 & \\
\hline
\end{tabular}

Do you know that waste mobile phones contain recyclable precious metal substanceslike gold, silver, or palladium?

\begin{tabular}{|ll|r|r|r|r|}
\hline & & & & \multicolumn{2}{c|}{$\begin{array}{c}\text { Cumulative } \\
\text { Percent }\end{array}$} \\
\hline Valid & Frequency & Percent & Valid Percent & 26.1 \\
& No & 6 & 26.1 & 26.1 & 30.4 \\
& Not sure & 1 & 4.3 & 4.3 & 100.0 \\
& Yes & 16 & 69.6 & 69.6 & \\
\hline & 23 & 100.0 & 100.0 & \\
\hline
\end{tabular}

Would you be willing to buy a used mobile phone? (refurbished or renovation mobile phone)

\begin{tabular}{|c|c|c|c|c|c|}
\hline & & Frequency & Percent & Valid Percent & $\begin{array}{c}\text { Cumulative } \\
\text { Percent }\end{array}$ \\
\hline \multirow[t]{4}{*}{ Valid } & depends on & 1 & 4.3 & 4.3 & 4.3 \\
\hline & No & 8 & 34.8 & 34.8 & 39.1 \\
\hline & Yes & 14 & 60.9 & 60.9 & 100.0 \\
\hline & Total & 23 & 100.0 & 100.0 & \\
\hline
\end{tabular}

D. Motivational, convenient, and ethics elements for returning the waste or unused mobile phone

For the responsibility of waste mobile phones recycling, consumers agree to share the responsibility, and it should also be shared the responsibility among government, manufacturers, and consumers. Assuming that the government forces individuals to carry their broken or unused handsets for recycling, the amount returned is in the range of $6 \%$ to more than $20 \%$ as expected. 
TABLE VII

If consumers have to return the waste mobile phone for recycling manufacturers, what percentage of original costs do you expect as reasonable price?

\begin{tabular}{|c|c|c|c|c|c|}
\hline & & Frequency & Percent & Valid Percent & $\begin{array}{l}\text { Cumulative } \\
\text { Percent }\end{array}$ \\
\hline \multirow[t]{10}{*}{ Valid } & $0.5 \%$ & 1 & 4.3 & 4.3 & 4.3 \\
\hline & $11-15 \%$ & 5 & 21.7 & 21.7 & 26.1 \\
\hline & $16-20 \%$ & 5 & 21.7 & 21.7 & 47.8 \\
\hline & $50.0 \%$ & 1 & 4.3 & 4.3 & 52.2 \\
\hline & $6-10 \%$ & 5 & 21.7 & 21.7 & 73.9 \\
\hline & I don't understand who's going to & & 43 & 43 & 783 \\
\hline & pay. & 1 & 4.3 & 4.3 & 18.3 \\
\hline & more than $21 \%$ & 4 & 17.4 & 17.4 & 95.7 \\
\hline & Up to $50 \%$ & 1 & 4.3 & 4.3 & 100.0 \\
\hline & Total & 23 & 100.0 & 100.0 & \\
\hline
\end{tabular}

For the collection process, people don't believe on vending machines as convenient products for the process, but as long as they return the money for consumers, people will accept to utilize it. IT solutions are efficiently to help swap waste or old or unused mobile phones because people like to sell them online; and websites could become bridges between consumers and manufacturers in order to collect the waste mobile phones. Thanks to IT solutions, it is very convenient for both consumers, manufacturers, retail stores, or government to first collect waste things and second protect in the environment.

TABLE VIII

Do you like vending machine using to collect waste mobile phone as a convenient product?

\begin{tabular}{|c|c|c|c|c|c|}
\hline & & Frequency & Percent & Valid Percent & $\begin{array}{c}\text { Cumulative } \\
\text { Percent }\end{array}$ \\
\hline \multirow[t]{3}{*}{ Valid } & No & 4 & 17.4 & 17.4 & 17.4 \\
\hline & Yes & 19 & 82.6 & 82.6 & 100.0 \\
\hline & Total & 23 & 100.0 & 100.0 & \\
\hline
\end{tabular}

Would you like to bring your waste mobile phone into the vending machines if they will pay money back for you?

\begin{tabular}{|c|c|c|c|c|c|}
\hline & & Frequency & Percent & Valid Percent & $\begin{array}{c}\text { Cumulative } \\
\text { Percent }\end{array}$ \\
\hline \multirow[t]{3}{*}{ Valid } & No & 5 & 21.7 & 21.7 & 21.7 \\
\hline & Yes & 18 & 78.3 & 78.3 & 100.0 \\
\hline & Total & 23 & 100.0 & 100.0 & \\
\hline
\end{tabular}

In the ethics situation, authors thought this will affect to campaigns which conducting by governments or manufacturers when they really practice in the near future. For instance, if people don't think classifying trash or garages as their habit, so it is tough for government to force them do it in the new regulations. However, we encourage the classification of waste in whatever position. $82.6 \%$ investigated people believed that the behavior of not putting electronic waste into recycling process is a moral violation because it will damage our environment; this awareness is crucial for future policies or activities.
TABLE IX

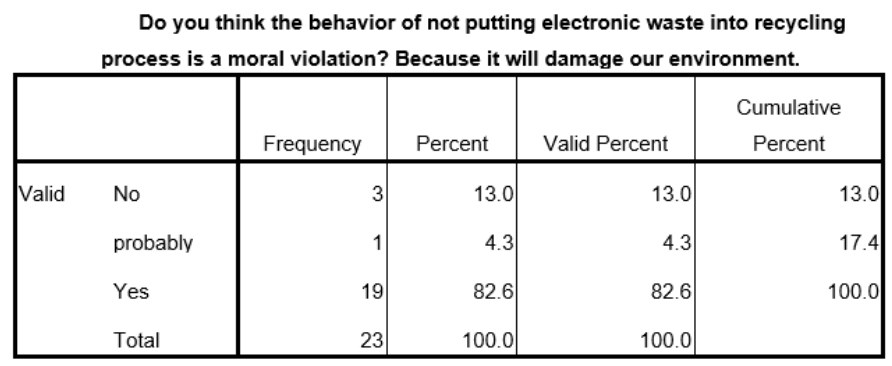

\section{CONCLUSION}

The aim of this paper was to collect valuable information about consumer's treatment for unused or waste mobile phone, consumers' environmental awareness, motivational, convenient, and ethics elements for returning the waste or unused mobile phone and then emphasize in doing business methods to protect the environments, particular with regard to waste mobile phones. Although there are many methods to implement, the sustainable method should be doing business for both government, consumers, and manufacturers. This research was investigated online throughout google forms tool for international students in some universities like Chung Yuan Christian, Asia, and Bac Lieu to find out the motivational, convenient, and ethics elements for returning the waste or unused mobile phone. After that, this paper should become a reference in understanding consumer behaviors in the habits versus waste mobile phones; and thus enterprises or government can do their new policies effectively. Consumers agree to share their responsibilities in waste mobile phones recycling. Authorities or leaders of companies related to this issues should have innovation ways to implement policies or strategies in order to both protecting the environment and earning profits.

This paper highly recommends the changing mindset that protection of the environment and economic growth should be seen as parallel benefits. For instance, thanks to the Glassplus project backed by the European Commission's Eco-Innovation program, people gather TV screens and then they are shredded and re-used to make ceramic tiles. "All of these operations are economically sustainable because this is a profitable business, my factory is making profit, creating jobs and has a selfsustaining system," says Bibiana Ferrari. The purpose of this process is not only environmentally-friendly, but it also attracts new markets throughout its ecological certification. Another program which should be highly appreciated is eco-friendly Green Box Program in China. The Greenbox program has already been started in many cities in China and it solved the problems related to waste electronic electricity equipment. The main program mission started with collecting waste things to the recycling process in final stage.

\section{ACKNOWLEDGMENT}

The author thanks students at Chung Yuan Christian university, Asia university (all in Taiwan), and Bac Lieu 
university (Vietnam) for providing practical support.

Tuan Hai Nguyen would like to express his gratitude to Asia university - Taiwan, department of business administration for financing his $\mathrm{PhD}$ scholarship and supporting conference fees.

\section{REFERENCES}

[1] Babatunde, O.A., Eguma, C.A., Oyeledun, B.T., Igwilo, O.C., Awosanya, O.G., Adegbenro, O., 2014. Mobile phone usage and battery disposal in Lagos, Nigeria. Int. J. Appl. Psycol. 4, 147-154.

[2] Barr, S., Gilg, A.W., Ford, N.J., 2001. A conceptual framework for understanding and analysing attitudes towards household-waste management. Environ. Plann. A, 33, 2025-2048. https://doi.org/10.1068/a33225

[3] Bouvier, R., Wagner, T., 2011. The influence of collection facility attributes on household collection rates of electronic waste: the case of televisions and computer monitors. Resour. Conserv. Recycl. 55, 10511059. https://doi.org/10.1016/j.resconrec.2011.05.019

[4] Miafodzyeva, S., Brandt, N., Andersson, M., 2013. Recycling behaviour of households living in multicultural urban area: a case study of Järva, Stockholm, Sweden. Waste Manage. Res. 31, 447-457. https://doi.org/10.1177/0734242X13476746

[5] Milovantseva, N., Saphores, J.-D., 2013. E-waste bans and U.S. households' preferences for disposing of their e-waste. J. Environ. Manage. 124, 8-16 https://doi.org/10.1016/j.jenvman.2013.03.019.

[6] Ni, H.G., Zeng, E.Y., 2009. Law enforcement and global collaboration are the keys to containing E-waste tsunami in China. Environ. Sci. Tech. 43 (11), $3991-3994$. https://doi.org/10.1021/es802725m

[7] Panambunan-Ferse, M., Breiter, A., (2013). Assessing the side-effects of ICT development: E-waste production and management: a case study about cell phone end-of-life in Manado, Indonesia. Technol. Soc. 35, $223-231$.

https://doi.org/10.1016/j.techsoc.2013.04.002

[8] Polák, M., Drápalová, L., 2012. Estimation of end of life mobile phones generation: the case study of the Czech Republic. Waste Manage. 32, $1583-1591$.

https://doi.org/10.1016/j.wasman.2012.03.028

[9] Rahmani, M., Nabizadeh, R., Yaghmaeian, K., 2014. Estimation of waste from computers and mobile phones in Iran. Resour. Conserv. Recy. 87, 21-29. https://doi.org/10.1016/j.resconrec.2014.03.009

[10] Ramayah, T., Lee, J.W.C., Lim, S., 2012. Sustaining the environment through recycling: an empirical study. J. Environ. Manage. 102, 141147 https://doi.org/10.1016/j.jenvman.2012.02.025.

[11] Robinson, B.H., 2009. E-waste: an assessment of global production and environmental impacts. Sci. Total Environ. 408, 183 - 191. https://doi.org/10.1016/j.scitotenv.2009.09.044

[12] Thomas, C., Sharp, V., 2013. Understanding the normalization of recycling behavior and its implication for other pro-environmental behaviours: a review of social norms and recycling. Resour. Conserv. Recycl. 79, 11-20. https://doi.org/10.1016/j.resconrec.2013.04.010

[13] Wagner, T.P., 2013. Examining the concept of convenient collection: an application to extended producer responsibility and product stewardship frameworks. Waste Manage. 33, 499-507. https://doi.org/10.1016/j.wasman.2012.06.015

[14] Wagner, T.P., Toews, P., Bouvier, R., 2013. Increasing the diversion of household hazardous wastes and materials through mandatory retail take-back. J. Environ. Manage. 123, 88-97. https://doi.org/10.1016/j.jenvman.2013.03.020 